\title{
高強度材料を用いた鉄筋コンクリート扁平梁構法の開発研究 DEVELOPMENT OF HIGH STRENGTH REINFORCED CONCRETE FLAT BEAM SYSTEM
}

\author{
西村 康志郎*1, 瀧 口克已*2, 堀田久人*3, 増井 靖*4 \\ 常木康 弘*5, 小板橋裕一 ${ }^{* 5}$, 中西規夫*5 \\ Koshiro NISHIMURA, Katsuki TAKIGUCHI, Hisato HOTTA, Yasushi MASUI, \\ Yasuhiro TSUNEKI, Yuichi KOITABASHI and Norio NAKANISHI
}

\begin{abstract}
$\mathrm{RC}$ flat beam system, which was rigid frame construction that consisted with $\mathrm{RC}$ flat beams and normal $\mathrm{RC}$ columns, were researched and developed in the previous study by the authors. The flat beam of this system has wider width than columns have and shorter depth than normal beams have. In this study, high strength RC was used for the flat beam system. In order to investigate performance of high strength $\mathrm{RC}$ flat beam system, cyclic loading tests of two beam-column joint specimens were carried out, which one is cruciform joint specimen, the other is corner joint specimen. As results, it can be said that there were no serious problem in this system. All the specimens showed restoring force characteristics of flexural type, and flexural strength could be estimated by traditional ways. An estimating method of stiffness of RC flat beam and column joint was shown in this paper.
\end{abstract}

Keywords : RC flat beam, high strength concrete, cruciform joint, corner joint, initial stiffness, yield point stiffness $\mathrm{RC}$ 扁平梁，高強度コンクリート，十字形接合部，卜字形接合部，初期剛性，降伏時剛性

1. 序

鉄筋コンクリート $(\mathrm{RC})$ の柱に幅の広い部材が取り付く接合部 に関しては，これまで RC フラットスラブやフラットプレートなど の研究があり ${ }^{1) \sim 7)}$, 筆者らも幅広で梁成の低い $\mathrm{RC}$ 扁平梁を用いた 構法の開発研究を行った ${ }^{8)}$ 。この開発研究では, $\mathrm{RC}$ 扁平梁と通常 の $\mathrm{RC}$ 柱の十字形接合部材について, 梁と柱の力の伝達や, 柱主筋 の付着について検討しており, 梁のヒンジ位置を柱面から少し離す, 柱に近い梁のコンクリート拘束を強める, 柱の主筋に添え筋をする, といった対策の効果を実験で確かめ, $\mathrm{RC}$ 扁平梁構法は可能である ことを確認した。この開発における扁平梁は, フラットプレートほ ど薄くなく，幅広にすることで剛性を確保できる程度の梁成のもの である。

近年, 建築物の高層化に伴い, 高強度コンクリートを使用する必 要性が増えている。高強度材料を用いると, 梁柱接合部に作用する 力の条件が厳しくなることが多い上に, $\mathrm{RC}$ 扁平梁と柱の接合部は, 通常の梁柱接合部と形状が異なるので, $\mathrm{RC}$ 扁平梁構法に高強度材 料を用いたときの影響を把握する必要がある。また, 以前の研究8) での試験体は全て十字形接合部材だったが，平面計画上，隅柱のあ
るところでは扁平梁が卜字形に接合するので, 卜字形接合部で扁平 梁と柱の間の力を円滑に伝達させることも課題として残っている。 これらを踏まえ, $\mathrm{RC}$ 扁平梁構法に高強度材料を使用すること, 扁 平梁を卜字形に柱へ接合させるための配筋，を検討するために，圧 縮強度約 $60 \mathrm{~N} / \mathrm{mm}^{2}$ のコンクリートと降伏強度約 $470 \mathrm{~N} / \mathrm{mm}^{2}$ の鉄筋 を用いた十字形接合部材と卜字形接合部材を各 1 体作製し, 変形漸 増繰り返し加力実験を行った。卜字形接合部材の梁主筋定着には, 機械式定着金物を使用した。本論文では, 復元力特性やひび割れに ついて考察し, 扁平梁・柱接合部材の初期剛性と降伏時剛性の評価 方法について述べる。

\section{2. 実験計画}

\section{1 試験体}

図 1 と図 2 に試験体図に示す。表 1 は試験体リストおよびコンク リートの力学特性, 表 2 は鉄筋の力学特性である。

試験体は，高強度材料を用いた RC の十字形とト字形の接合部材 が各 1 体 (以下, HRC-1, HRC-2), 計 2 体である。試験体は, 実 物の $1 / 5$ を想定したものだが, 試験装置の都合で梁を長くしたので,

\footnotetext{
*1 東京工業大学 助教 $\cdot$ 博士 (工学)

*2 東京工業大学 教授. 工博

*3 東京工業大学 准教授・博士 (工学)

*4 住友不動産(株

* 5 (株)日建設計
}

Assistant Prof., Tokyo Institute of Technology, Dr. Eng.

Prof., Tokyo Institute of Technology, Dr. Eng.

Assoc. Prof., Tokyo Institute of Technology, Dr. Eng.

Sumitomo Realty \& Development Co., Ltd.

NIKKEN SEKKEI Ltd. 


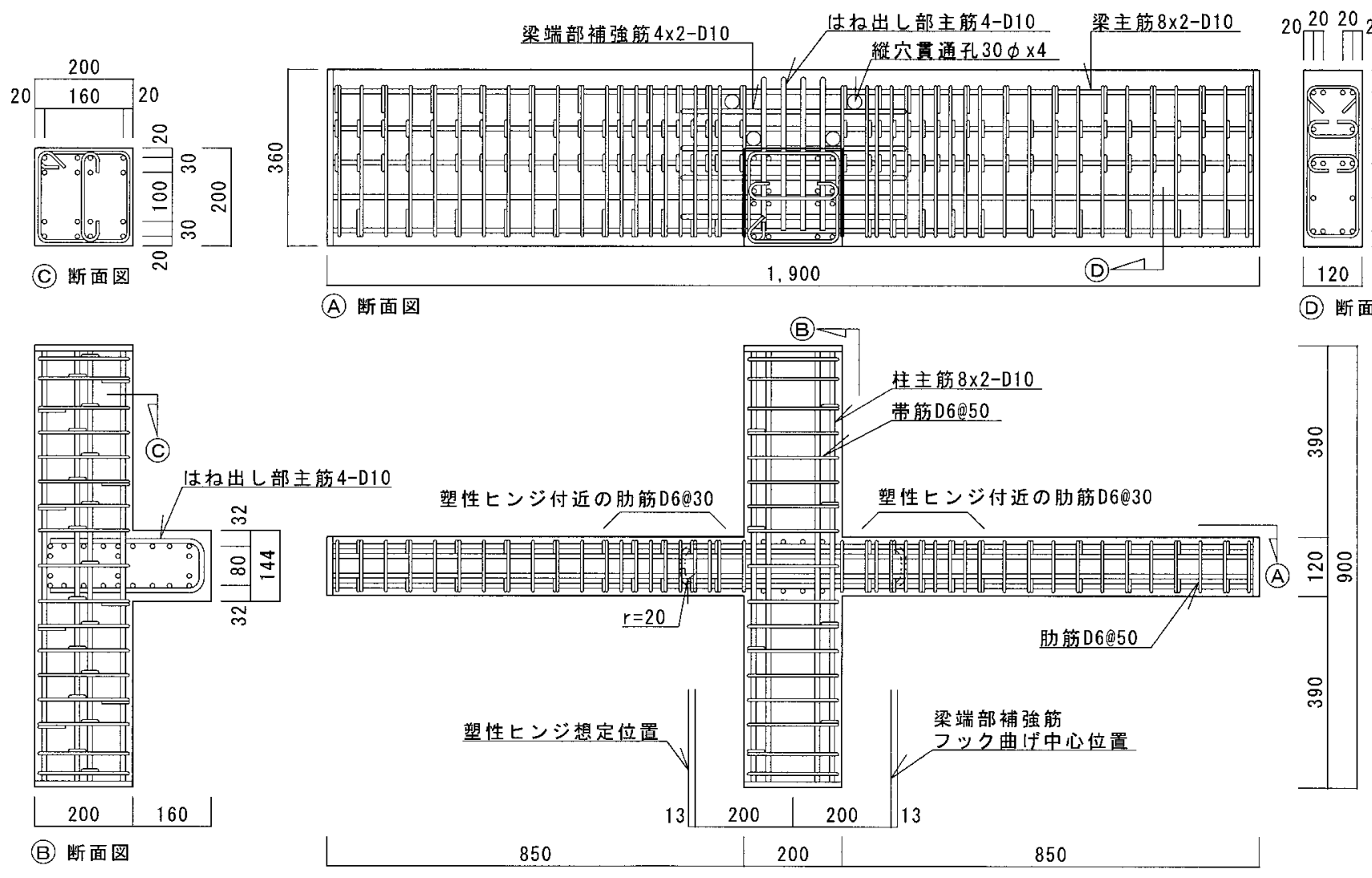

図 1 HRC-1［十字形接合部材］試験体図

試験体の梁のせん断スパンは，想定した実物寸法を縮小したせん断 スパンよりも7/5倍大きい。コンクリートシリンダー圧縮強度は約 $60 \mathrm{~N} / \mathrm{mm}^{2}$, 主筋に用いた異形鉄筋 D10の降伏強度は $466 \mathrm{~N} / \mathrm{mm}^{2}$ で ある。 2 体とも, 柱芯と梁芯を偏心させて接合した形状である。建 築計画上の自由度を拡げる目的で直径 $30 \mathrm{~mm}$ の配管用の縦穴貫通孔 を接合部付近に設け，その影響を調べた。コンクリートの養生は， 14日間湿潤養生した後に脱型し，その後気中養生とした。

2 体の試験体には，梁端部補強筋，はね出し部主筋，塑性ヒンジ 想定位置付近の密なあばら筋を配した。梁端部補強筋は，梁の塑性 ヒンジ位置を柱面から離す為の補強筋で，梁の接合部位置に上下そ

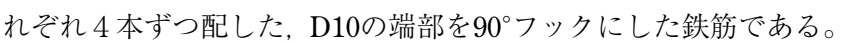
塑性ヒンジ想定位置は, 梁端部補強筋のフック曲げ中心からフック 半径 $\mathrm{r}$ の $2 / 3$ 倍（13mm）の位置と仮定した。密なあばら筋は塑性 ヒンジ付近のコンクリート拘束を強める為の補強筋である。はね出 し部主筋は，D10をコの字形に曲げた鉄筋で，梁柱接合部における 扁平梁のはねだし部分に 4 本配筋した。はね出し部主筋のかぶり厚 を確保するため, 接合部のはね出し部分の成は梁成より $24 \mathrm{~mm}$ 厚く なっている。

試験体 HRC-2では, 梁主筋と梁端部補強筋を, 図 3 に示す機械 式定着金物を用いて定着した。機械式定着金物については，定着金 物付き鉄筋の引張試験により，定着金物から鉄筋が抜けずに鉄筋が 破断することを確認した ${ }^{9)}$ 。接合部のはね出し部分から梁の塑性ヒ ンジ想定位置にかけて，はね出し部補強筋を配した。はね出し部補 強筋とは D13を四角形に曲げた鉄筋であり，梁成の中心位置に配筋 した。

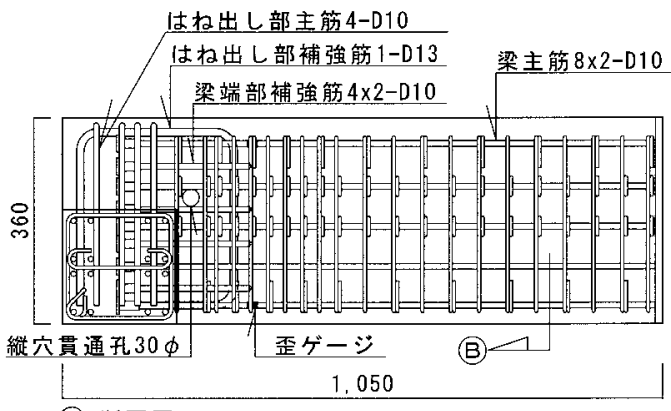

(A) 断面図
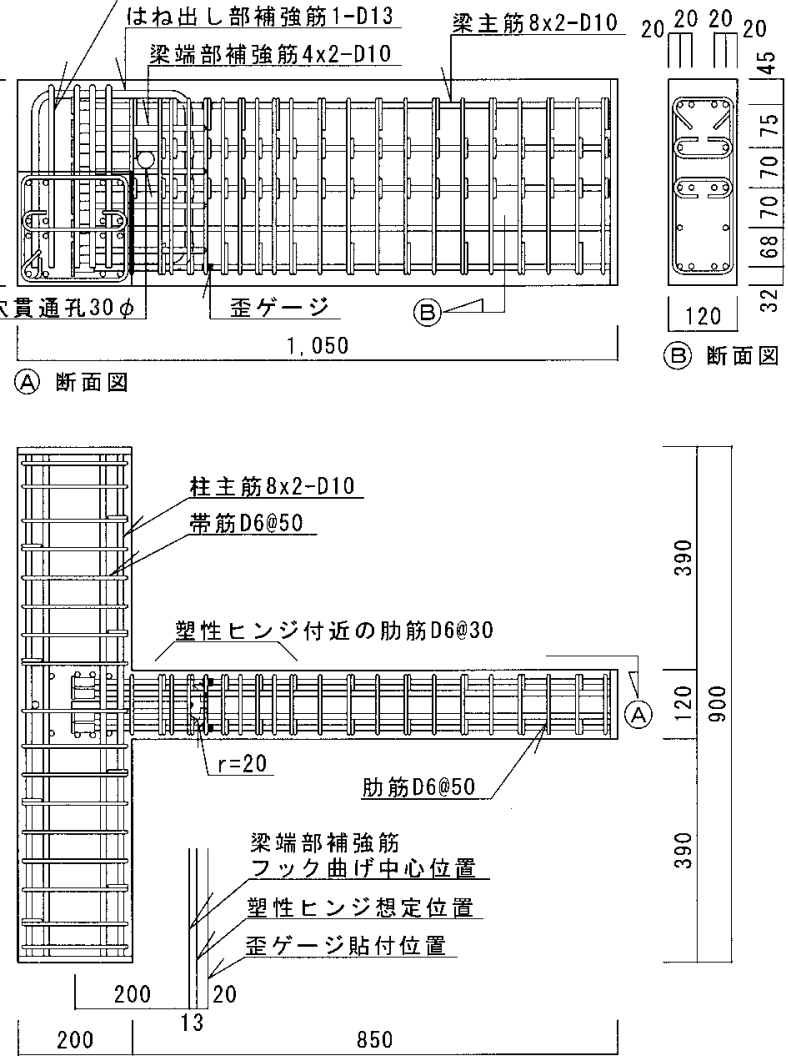

図2ＨRC-2［ト字形接合部材］試験体図 
表 1 試験体リストおよびコンクリートの材料特性

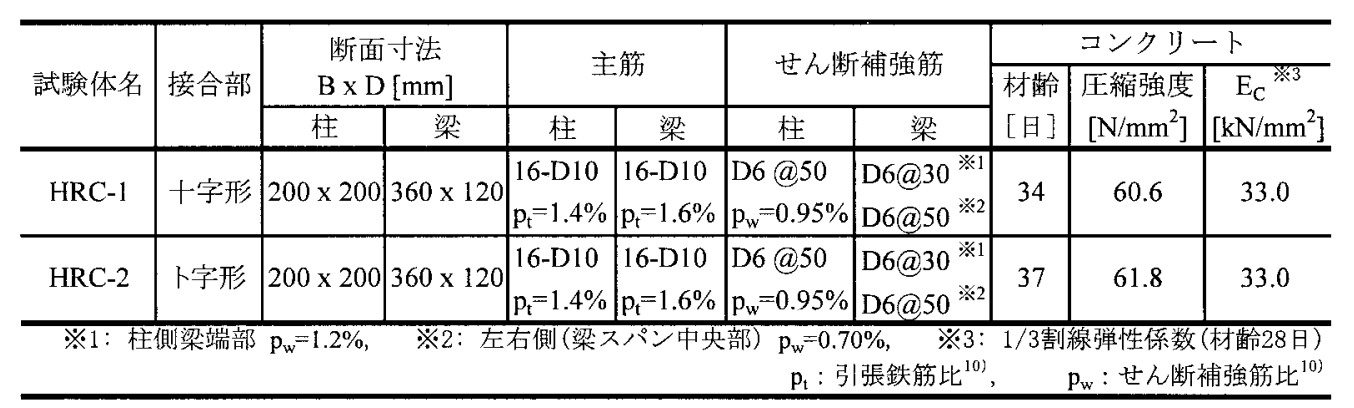

表 2 異形鉄筋の材料特性

\begin{tabular}{c|c|c|c}
\hline & $\mathrm{D} 6$ & $\mathrm{D} 10$ & $\mathrm{D} 13$ \\
\hline $\begin{array}{c}\text { 公称断面積 } \\
{\left[\mathrm{mm}^{2}\right]}\end{array}$ & 31.67 & 71.33 & 126.7 \\
\hline $\begin{array}{c}\text { 降伏強度 } \\
{\left[\mathrm{N} / \mathrm{mm}^{2}\right]}\end{array}$ & $419 *$ & 466 & 366 \\
\hline $\begin{array}{c}\text { 引張強度 } \\
{\left[\mathrm{N} / \mathrm{mm}^{2}\right]}\end{array}$ & 600 & 656 & 515 \\
\hline $\begin{array}{c}\text { ヤング率 } \\
{\left[\mathrm{kN} / \mathrm{mm}^{2}\right]}\end{array}$ & 201 & 202 & 196 \\
\hline
\end{tabular}

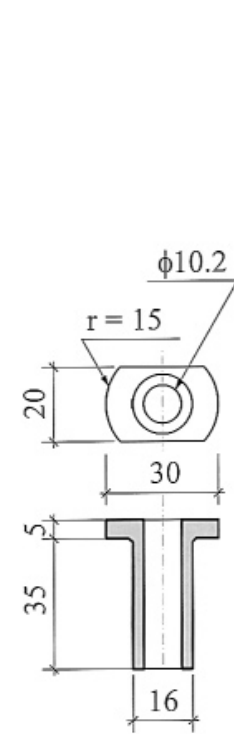

図 3 機械式定着金物

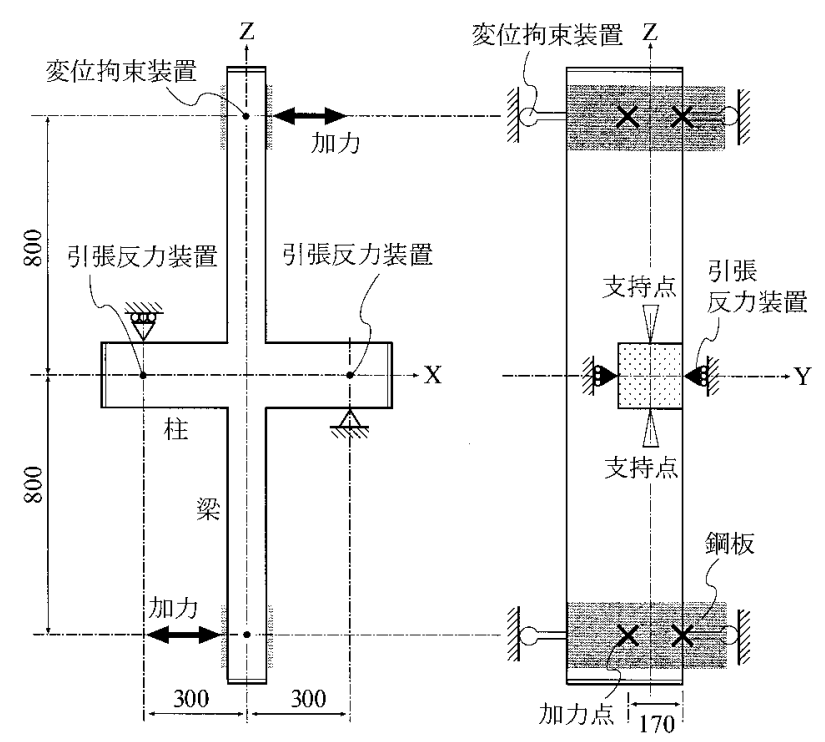

図4 加力システム概念図 (HRC-1)
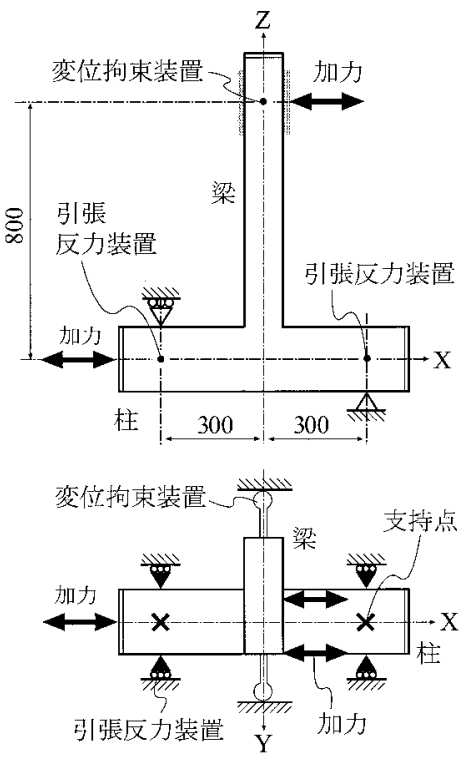

図 5 加力システム概念図（HRC-2）
試験体 HRC-2の主筋には, 図 2 に示す位置に歪ゲージを貼付し た。歪ゲージの位置は塑性ヒンジ想定位置から $20 \mathrm{~mm}$ 離れた位置で, 四隅の梁主筋 4 本に表裏 1 枚ずつ計 8 枚貼付した。

試験体 HRC-1の柱主筋量と梁端部補強筋量は, 梁の塑性ヒンジ 想定位置で降伏すると仮定したときの，梁端部および柱端部の曲げ モーメントをそれぞれの設計用曲げモーメントとし，設計用曲げ モーメントに対する断面の曲げ強度の比で1.3倍以上になるように した。梁と柱の曲げ強度の算定には, 日本建築学会の鉄筋コンクリー 卜構造計算規準 ${ }^{10)}$ (以下, $\mathrm{RC}$ 規準) の梁の降伏曲げモーメントの 略算式を用いた。また，柱主筋については，接合部における柱主筋 の付着に関して, RC 規準 ${ }^{10)}$ の17条21式を満足するように設計した。 このとき，17条21式で用いる主筋の応力については，柱端部断面に おいて，コンクリートと鉄筋を線形弾性体（コンクリートは引張応 力を負担しない）とし，設計用曲げモーメントと，作用軸力が零の 条件を用い，平面保持を仮定して算出した引張鉄筋の応力とした ${ }^{8)}$ 。

試験体 HRC-2の柱と梁の主筋本数揖よび梁端部補強筋の本数は, 試験体 HRC-1と同じにした。

\section{2 載荷システムおよび加力計画}

図 4 と図 5 に示すように，柱をピン・ローラーで支持し，梁を油 圧ジャッキで加力した。加力部分では，厚さ $22 \mathrm{~mm}$ の鋼板で梁を挟 んだ。図 4,5のX軸回りの回転は, 梁の両側の変位拘束装置で拘 束されている。片側の梁への加力に油圧ジャッキを 2 本使い, 加力 位置で梁が㧖れない様な載荷を可能にした。卜字形の試験体では,

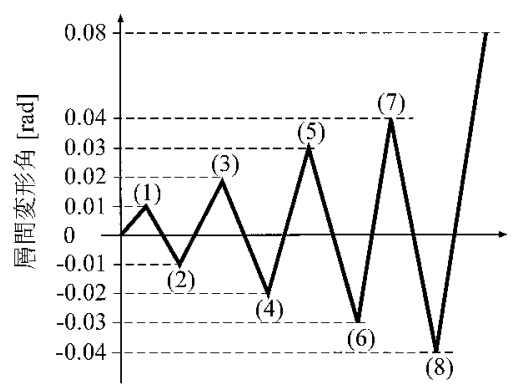

図6 加力計画

ローラー支承側の柱に油圧ジャッキを取り付け, 梁への荷重の反力 を受けるようにした。図 5 に示すように, 加力点と支持点は同一平 面上になく, $Z$ 軸回りの偶力が発生するため, 柱の両側に取り付け た引張反力装置で反力を受けるようにした。引張反力装置は, 試験 体に固定した PC 鋼棒に引張力のみ作用するようにした装置であ る。十字形の試験体でも，4本の油圧ジャッキの力のバランスによっ ては $Z$ 軸回りの偶力が発生するので, 柱の両側に引張反力装置を 取り付けた。変形測定については, 梁の加力位置の変位を変位計で 測定した。

図 6 に示すように, 加力計画は正負交番変位漸増繰り返し加力で,

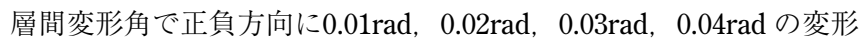
をそれぞれ 1 回ずつ与え, 最後に正方向へ0.08 $\mathrm{rad}$ まで変形させて 除荷した。 


\section{3. 実験結果および考察}

\section{1 復元力特性}

図 7 に試験体 HRC-1 と HRC-2の層間変形角 $R$ と梁せん断力 $Q_{B}$ の 関係を示す。層間変形角は, 梁の加力位置での変位を接合部の中心 から梁の加力点までの距離で除した值である。試験体 HRC-1の梁 せん断力と加力位置の変位は, 2 つの梁の平均值とした。図 7 には, $2 つ の$ 曲げ強度算定值を併せて示した。2つの算定值は, それぞれ， $\mathrm{RC}$ 規準 ${ }^{10)}$ にある降伏曲げモーメントの略算式と累加強度 ${ }^{11)}{ }^{12)}$ を 用いて算出した值である。 $\mathrm{RC}$ 規準 ${ }^{10)}$ の略算式による降伏曲げモー メント $M_{y}$ は， 2 段配筋の梁なので 1 段目と 2 段目の計算值を足し 合わせ，次式で算出した。

$$
M_{y}=0.9 \cdot \sigma_{y} \cdot\left(a_{t 1} \cdot d_{1}+a_{t 2} \cdot d_{2}\right)
$$

ここで， $a_{t}$ と $d$ の右下添え数字は，それぞれ，1段目および 2 段目 の引張側鉄筋断面積と有効成を表している。 $\sigma_{y}$ は引張鉄筋の降伏 強度である。累加強度の算定では，鉄筋とコンクリートの材料特性 を剛塑性とし，ベクトル和が最大になるように，それぞれの強度曲 線を足し合わせた。材料の降伏強度には, 表 1 のコンクリート圧縮 強度の0.85倍と表 2 の鉄筋の降伏強度を用いた。

図 7 より, 2 体とも大変形時の耐力低下はほとんどなく, 履歴ルー プも良好と言える。試験装置の都合で梁のせん断スパンを長くした ため, 降伏時の変形は大きくなっている。縦穴貫通孔から伸びるひ び割れは多少見られたが，大きく広がることはなく， $R-Q_{B}$ 関係に は縦穴貫通孔の影響は見られなかった。梁の変形は，2体とも塑性 ヒンジ想定位置付近に集中した。

2 体の試験体ともに, $\mathrm{RC}$ 規準の略算式による曲げ強度算定值で
降伏強度を, 累加強度による曲げ強度算定值で終局強度を評価でき ている。試験体 HRC-2の $R-Q_{B}$ 関係は, 試験体 HRC-1に比べて, 全 体的に剛性がやや高くなっている。これは, 梁が片側しかなく, 柱 と接合部に作用するせん断力が約半分となったためと考えられる。

\section{2 ひび割れの様子と梁主筋の歪}

図 8 に, 試験体 HRC-2の梁主筋の歪と計測ステップの関係を示 す。横軸は計測ステップで, 横軸の番号は図 6 の加力計画の番号と 対応している。縦軸の歪は引張を正としている。降伏歪は, 表 2 の 降伏強度をヤング係数で除したものである。図 9, 図10に, それぞ れ, 試験体 HRC-1 と HRC-2の層間変形角 $0.02 \mathrm{rad}$ のきのひび割れ 図, 試験体 HRC-2の載荷後の写真, を示す。

試験体 HRC-1では, 曲げひび割れが, 最初に扁平梁の塑性ヒン ジ想定位置付近, 次に柱面付近で確認された。その後, 層間变形角 0.01radに至るまでに，接合部の柱側の側面にせん断ひび割れが生 じた。層間変形角0.02rad の変形時には，接合部のはね出し部表面 に据れによるひび割れ，柱の曲げひび割れや曲げせん断ひび割れが 確認された。層間変形角 $0.07 \mathrm{rad}$ 付近で, 接合部のはね出し側の側 面にせん断ひび割れが生じ, 僅かな耐力低下が見られたが, その後, 層間変形角 $0.08 \mathrm{rad}$ までそれ以上の耐力低下は無かった。大变形時 には, 梁の塑性ヒンジ想定位置から柱面の間で梁のコンクリートの 圧壊が顕著だった。

試験体 HRC-2のひび割れの様子は試験体 HRC-1と似ていたが, 接合部のはね出し部の側面において, 試験体 HRC-1よりもひび割 れが目立った。また，試験体 HRC-1で見られたような，接合部の はね出し部の側面のせん断ひび割れは生じなかった。層間変形角
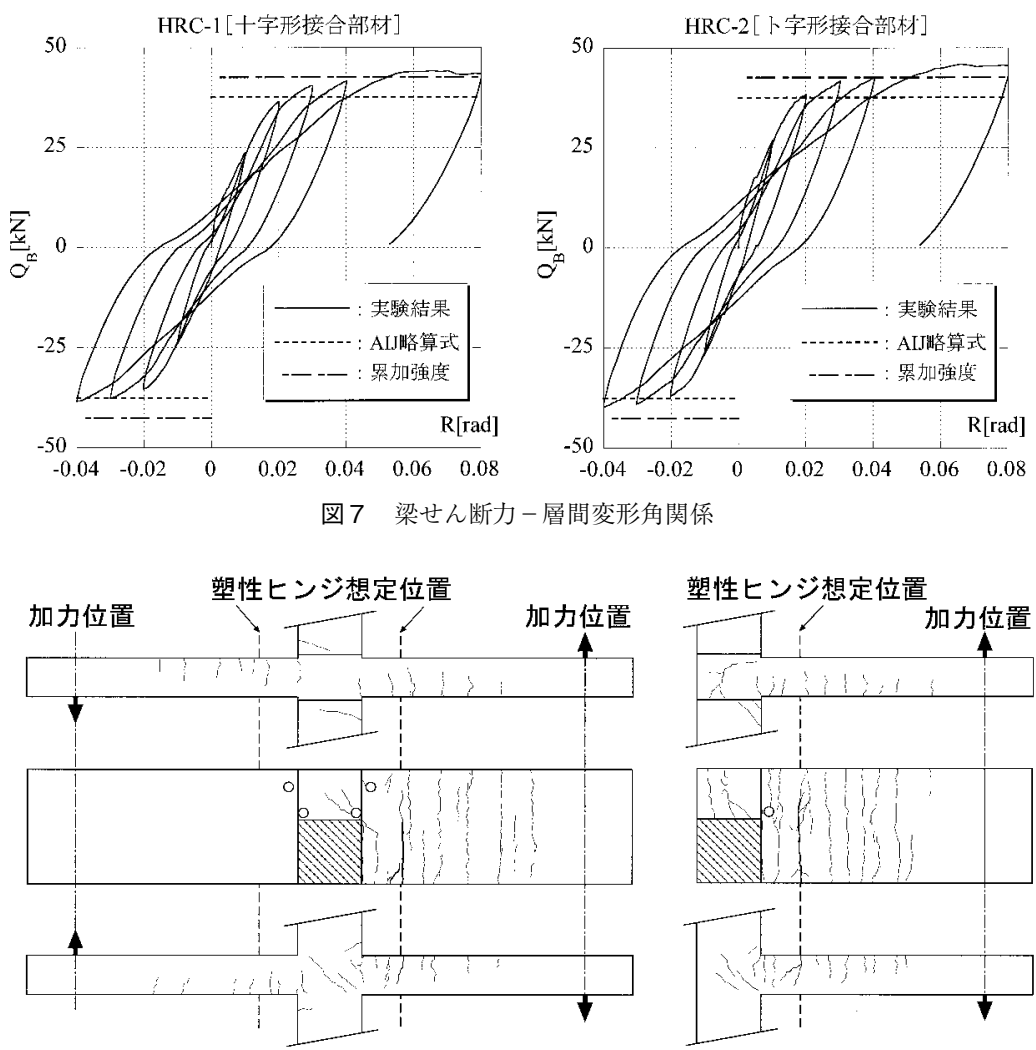

(a) HRC-1

(b) HRC-2

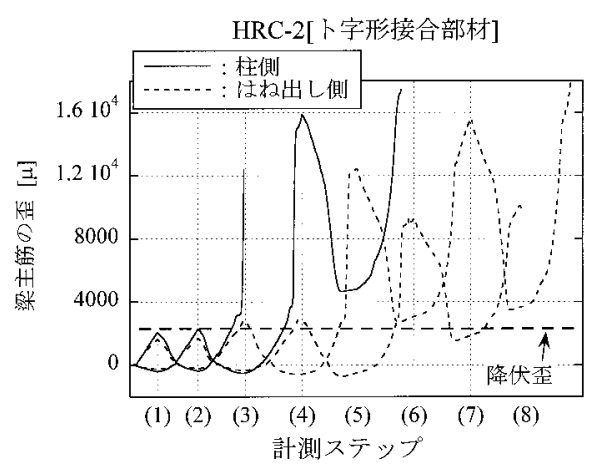

図 8 梁主筋の歪と計測ステップの関係

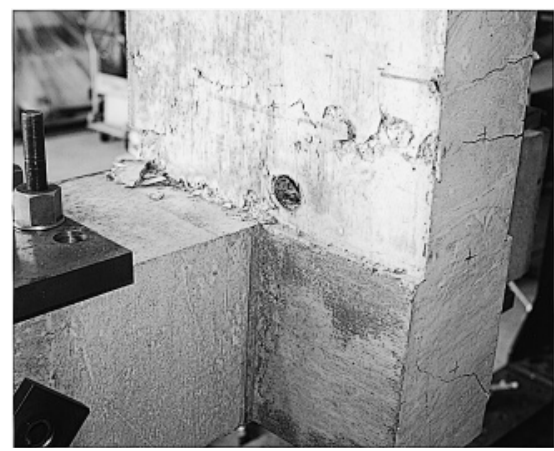

図10載荷終了後の写真（HRC-2） 
0.01radに至るまでに，接合部はね出し部側面の定着金物の位置に ひび割れが生じ，定着金物の影響が見られた（図 9 参照)。図 8 に 示すように，梁主筋の引張歪が柱側よりもはね出し側のほうが若干 小さかったのは，定着金物位置で生じたひび割れのところで多少の 回転があったためと思われる。しかし，梁主筋の歪は，柱側とはね 出し側でほぼ同じ挙動だったと言え，復元力特性には，接合部のは ね出し部の側面に生じたひび割れの影響はほとんど見られなかっ た。

\section{3 補強筋の改良案}

図11(a)に示すように，耐力低下はほとんどなかったものの，試験 体 HRC-1では接合部のはね出し部側面に，層間変形角0.07 $\mathrm{rad}$ 付近 でせん断ひび割れが生じた。接合部のはね出し部では㨭れが作用し ている。図11(b)に示すように，はね出し部の断面を3つに分けて考 えると，せん断ひび割れは断面 $\mathrm{b} の$ 部分に生じており，はね出し 部主筋のある断面 $\mathrm{a}$ と $\mathrm{a}^{\prime}$ がそれぞれ左右逆向きのせん断力を負担 することで据れに抵抗できる。また，はね出し部側面付近では，は ね出し部主筋のコの字形の梁成方向部分がせん断ひび割れの拡大を 防いだと考えられる。これらが，接合部に生じたせん断ひび割れに よる耐力低下がほとんどなかった理由と思われる。図11(c)に示すよ うに，接合部のはね出し部に，梁成方向の鉄筋やせん断補強筋を配 することは，据れに対する補強やせん断ひび割れ防止に有効と考え られる。

試験体 HRC-2では，梁主筋と梁端部補強筋を機械式定着金物で 定着したが，図12(a)(b)に示すように，接合部はね出し部の定着位置 でひび割れて回転し, 定着金物より奥の部分が取り残される形と なった。梁端部補強筋を, 図12(c)に示すように, はね出し部を囲う ような形の配筋が有効と思われる。

\section{4. 扁平梁・柱接合部材の剛性評価}

\section{1 剛性評価方法の概要}

図13に示す扁平梁・柱接合部材を, 図14に示す線材モデルに置き 換えて，剛性を評価する方法について述べる。

接合部では, 図13のように, 柱と取り合う部分 $\mathrm{A}$ と, はね出し ている部分 B に分けられる。柱からの力は部分 $\mathrm{A}$ に作用し, 梁か らの力には, 部分 $\mathrm{A}$ に直接作用する力と部分 $\mathrm{B}$ を介して部分 $\mathrm{A}$ に 作用する力がある。結局, 梁と柱からの力は, 部分 $\mathrm{A}$ に作用する ので, 図14のモデルの接合部パネルは部分 Aのみ考慮すれば良い と考えられる。接合部パネルの奥行きを柱幅 $B_{C}$ とする。接合部パ ネルではコンクリート部分のせん断変形のみを考慮する。接合部パ ネルのせん断力ーせん断変形関係は, せん断ひび割れの発生などに より非線形となる。しかし, 梁や柱の曲げひび割れ後では, 梁柱接 合部材の変形は梁や柱の変形が支配的になると考えられる。接合部 パネルでの力ー変形関係の非線形性の考慮の有無が, 梁柱接合部材 の剛性評価の精度に与える影響は比較的少ないと判断し, 剛性評価 方法を簡易にするために，接合部パネルは弾性を仮定した。

試験体 HRC-2の歪のデータや, 以前行った研究8) での歪のデータ より, 扁平梁における梁幅方向の鉄筋の応力のバラッキは少ないの で，扁平梁を全幅有効な梁として線材に置き換えた。

梁柱接合部材の層間変形は, 梁と柱と接合部パネルの変形の和と なる。梁と柱を片持ち梁としたときの荷重－変位関係の剛性をそれ ぞれ $K_{B}$ と $K_{C}$ とすると, 梁柱接合部材の層間変形角 $R$ と梁せん断 力 $Q_{B}$ の関係は次式となる。

$$
\frac{R}{Q_{B}}=\frac{1}{L_{B} \cdot K_{B}}+\frac{L_{B}}{k_{T} \cdot L_{C}^{2} \cdot K_{C}}+\frac{k_{P}\left(2 L_{B}-D_{B} \cdot L_{B} / L_{C}-D_{C}\right)^{2}}{2 \cdot k_{T} \cdot G_{C} \cdot D_{C} \cdot B_{C} \cdot D_{B} \cdot L_{B}}
$$
接合部パネルの形状係数 $k_{P}$ は 1.0 とする。ポアソン比 $v$ を 0.2 とし, 表 1 のコンクリートのヤング係数 $E_{C}$ を用い, コンクリートのせん

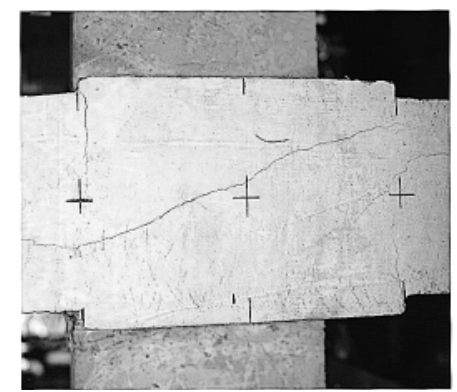

(a) 載荷後の写真

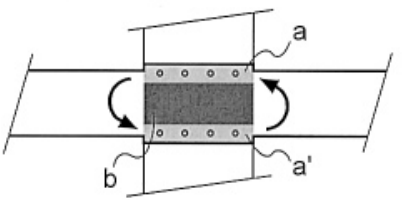

(b) はね出し部断面

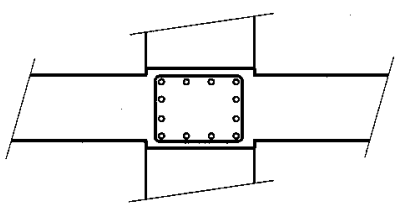

(c) 補強筋の改良案

図11 補強筋の改良案（HRC-1）

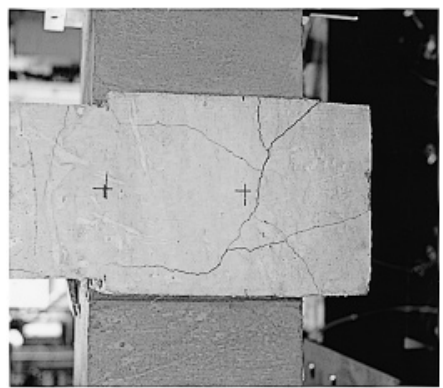

(a) 載荷後の写真

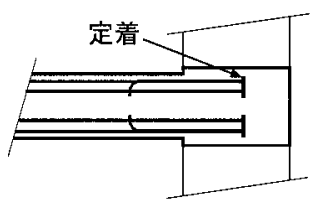

(b) 梁主筋定着位置

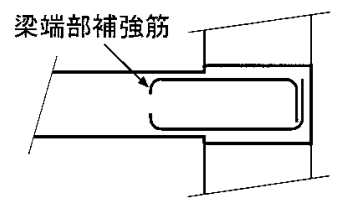

(c) 補強筋の改良案

図12 補強筋の改良案（HRC-2）

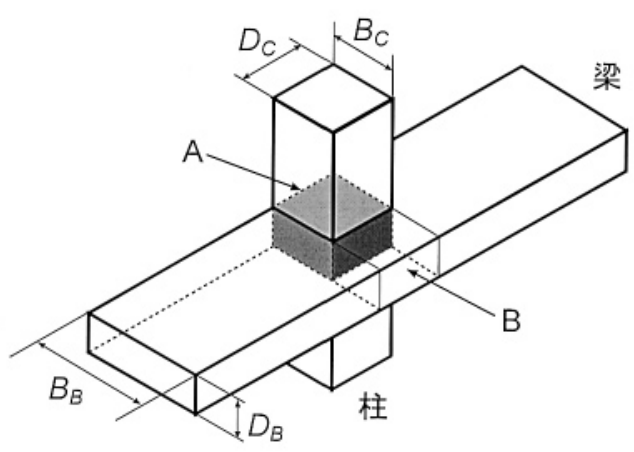

図13 扁平梁·柱接合部材図

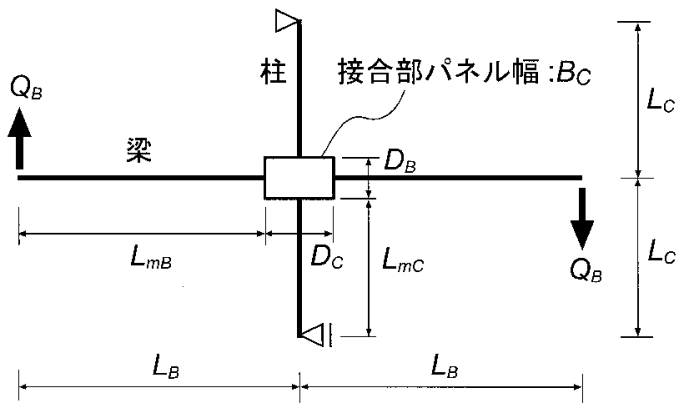

図14線材と接合部パネルの接合部材モデル 
表3 既往の研究8におおる試験体の諸元およびコンクリートの力学特性

\begin{tabular}{|c|c|c|c|c|c|c|c|c|c|c|c|c|}
\hline \multirow{3}{*}{ 試験体名 } & \multirow{3}{*}{ 形状 } & \multirow{2}{*}{\multicolumn{2}{|c|}{$\begin{array}{l}\text { 断面寸法 } \\
\text { bx D[mm] }\end{array}$}} & \multicolumn{2}{|c|}{ 主筋 } & \multicolumn{2}{|r|}{ せん断補強筋 } & \multirow{3}{*}{$\begin{array}{l}\text { 梁端部 } \\
\text { 補強筋 }\end{array}$} & \multirow{3}{*}{$\begin{array}{c}\text { はね出し部 } \\
\text { 主筋 } \\
\text { (偏心タイプのみ) }\end{array}$} & \multicolumn{3}{|c|}{ コンクリート } \\
\hline & & & & \multirow{2}{*}{ 柱 } & \multirow{2}{*}{ 梁 } & \multirow{2}{*}{ 柱 } & \multirow{2}{*}{ 梁 } & & & \multirow{2}{*}{$\begin{array}{l}\text { 材䠛 } \\
{[\text { 日] }}\end{array}$} & \multirow{2}{*}{$\begin{array}{l}\text { 圧縮強度 } \\
{\left[\mathrm{N} / \mathrm{mm}^{2}\right]}\end{array}$} & \multirow{2}{*}{$\begin{array}{c}\mathrm{E}_{\mathrm{C}}{ }^{\circledast 3} \\
{\left[\mathrm{kN} / \mathrm{mm}^{2}\right]}\end{array}$} \\
\hline & & 柱 & 梁 & & & & & & & & & \\
\hline \multirow{2}{*}{$\mathrm{RC}-1$} & \multirow{3}{*}{$\begin{array}{l}\text { 標準 } \\
\text { タイプ }\end{array}$} & \multirow{3}{*}{$\begin{array}{c}240 \\
x \\
240 \\
\end{array}$} & \multirow{3}{*}{$\begin{array}{c}500 \\
x \\
160\end{array}$} & \multirow{3}{*}{$\begin{array}{l}10-\mathrm{D} 13 \\
\mathrm{p}_{\mathrm{t}}=1.1 \%\end{array}$} & \multirow{3}{*}{$\begin{array}{l}16-\mathrm{D} 10 \\
\mathrm{p}_{\mathrm{t}}=0.82 \%\end{array}$} & \multirow{3}{*}{$\begin{array}{l}\mathrm{D} 6 @ 50 \\
\mathrm{p}_{\mathrm{w}}=0.79 \%\end{array}$} & $\mathrm{D} 6 @ 50\left(\mathrm{p}_{\mathrm{w}}=0.51 \%\right)^{* 1}$ & \multirow{2}{*}{ 8-D10 } & & \multirow{2}{*}{29} & \multirow{2}{*}{34.8} & \multirow{2}{*}{24.9} \\
\hline & & & & & & & D6@ $100, \mathrm{p}_{\mathrm{w}}=0.25 \%{ }^{* 2}$ & & & & & \\
\hline $\mathrm{RC}-4$ & & & & & & & D6@100, $p_{w}=0.25 \%$ & $\begin{array}{l}\text { 無L } \\
\end{array}$ & & 34 & 37.8 & 24.9 \\
\hline \multirow{2}{*}{ RC-5 } & \multirow{3}{*}{$\begin{array}{l}\text { 偏心 } \\
\text { タイプ }\end{array}$} & \multirow{3}{*}{$\begin{array}{c}240 \\
x \\
240 \\
\end{array}$} & \multirow{3}{*}{$\begin{array}{c}500 \\
x \\
160 \\
\end{array}$} & \multirow{3}{*}{$\begin{array}{l}10-\mathrm{D} 13 \\
\mathrm{p}_{\mathrm{t}}=1.1 \%\end{array}$} & \multirow{3}{*}{$\begin{array}{l}12-\mathrm{D} 10 \\
\mathrm{p}_{\mathrm{t}}=0.61 \%\end{array}$} & \multirow{3}{*}{$\begin{array}{l}\mathrm{D} 6 @ 50 \\
\mathrm{p}_{\mathrm{w}}=0.79 \%\end{array}$} & $\mathrm{D} 6 @ 50\left(\mathrm{p}_{\mathrm{w}}=0.51 \%\right)^{* 1}$ & \multirow{2}{*}{$6-\mathrm{D} 10$} & \multirow{2}{*}{$5-\mathrm{D} 13$} & \multirow{2}{*}{33} & \multirow{2}{*}{37.7} & \multirow{2}{*}{26.5} \\
\hline & & & & & & & $\mathrm{D} 6 @ 100, \mathrm{p}_{\mathrm{w}}=0.25 \%{ }^{* 2}$ & & & & & \\
\hline $\mathrm{RC}-7$ & & & & & & & D6@100, $\mathrm{p}_{\mathrm{w}}=0.25 \%$ & 無L & 無乙 & 37 & 38.4 & 26.5 \\
\hline
\end{tabular}

表 4 既往の研究 ${ }^{8)}$ における試験体の 鉄筋の材料特性

\begin{tabular}{c|c|c|c}
\hline & $\mathrm{D} 6$ & $\mathrm{D} 10$ & $\mathrm{D} 13$ \\
\hline $\begin{array}{c}\text { 公称断面積 } \\
{\left[\mathrm{mm}^{2}\right]}\end{array}$ & 31.67 & 71.33 & 126.7 \\
\hline $\begin{array}{c}\text { 降伏強度 } \\
{\left[\mathrm{N} / \mathrm{mm}^{2}\right]}\end{array}$ & $497 *$ & 356 & 363 \\
\hline $\begin{array}{c}\text { 引張強度 } \\
{\left[\mathrm{N} / \mathrm{mm}^{2}\right]}\end{array}$ & 675 & 509 & 515 \\
\hline $\begin{array}{c}\text { ヤグ率 } \\
{\left[\mathrm{kN} / \mathrm{mm}^{2}\right]}\end{array}$ & 198 & 194 & 192 \\
\hline \multicolumn{3}{|c|}{$* 0.2 \%$ オフセット法 }
\end{tabular}

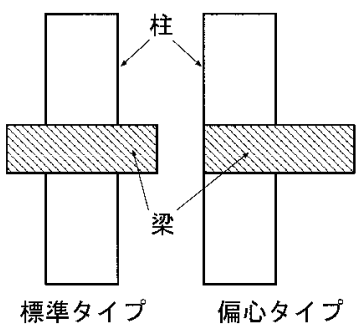

図15 扁平梁と柱の接合位置
断弾性係数 $G_{C}$ を $G_{C}=E_{C} / 2(1+v)$ の関係より算出した。 $k_{T}$ は，十

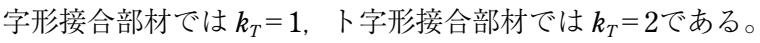

梁と柱の力 - 変形関係を, それぞれ，ひび割れ点と降伏点を持つ 3 折線とする。梁柱接合部材のせん断力 一層間変形角関係は, 梁と 柱の曲げひび割れ点, および, 梁の降伏点, の 3 つの折点を持つ 4 折線となる。

\section{2 初期剛性}

初期曲げ剛性では鉄筋を考慮した。矩形の $\mathrm{RC}$ 断面の寸法を $B \times D$, 鉄筋 1 本の断面積を $a$, 断面の対称軸から各鉄筋までの距離を $h$, コンクリートに対する鉄筋のヤング係数比を $n$ とし，等価断面二

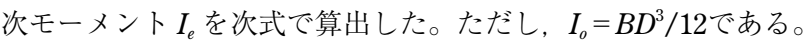

$$
I_{e}=I_{o}+n \cdot \sum_{i} a_{i} \cdot h_{i}^{2}
$$

梁や柱の初期剛性の算出において, 全変形をせん断変形と曲げ変 形の和と考えると, 片持ち梁の荷重 $Q$ と変位 $\delta$ の関係は次式とな る。

$$
\delta=\left(\frac{L_{m}^{3}}{3 E_{c} \cdot I_{e}}+\frac{k_{m} \cdot L_{m}}{B \cdot D \cdot G_{c}}\right) Q
$$

$L_{m}$ は部材長さ (図14の $L_{m B}$ または $L_{m C}$ ) で, 形状係数 $k_{m}$ は 1.2 とした。 式(4)より梁と柱の初期剛性 $K_{B I}$ と $K_{C I}$ が得られ，式(2)の $K_{B}$ と $K_{C} に$ それぞれ代入する。

柱と梁の曲げひび割れモーメント $M_{c}(\mathrm{~N} \cdot \mathrm{mm})$ の算出には, $\mathrm{RC}$ 規 準 ${ }^{10)}$ にある次式を用いた。

$$
M_{c}=0.56 \cdot \sqrt{\sigma_{B}} \cdot Z_{e}+N D / 6
$$

$\sigma_{B}$ にはコンクリートシリンダー圧縮強度を用いた。 $N$ は軸力, $D$ は部材成， $Z_{e}$ は鉄筋を考慮した断面係数で, $Z_{e}=2 I_{e} / D$ とした。

剛性評価方法の検証には, 試験体 HRC-1と HRC-2に加え, 文献 8) の試験体 RC-1， RC-4， RC-5， RC-7も用いる。試験体 RC-1， RC-4,

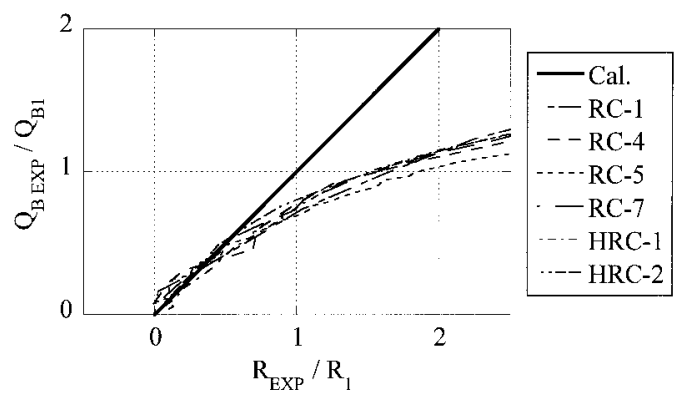

図16初期剛性の計算結果と実験結果の比較

RC-5，RC-7は全て十字形接合部材で，これらの諸元を表 3 に，鉄 筋の材料特性を表 4 に示す。図15に示すように，標準タイプは梁芯 と柱芯を合わせた形状で，偏心タイプは梁芯と柱芯をずらした形状 である。加力方法は図14の方法で, $L_{B}=800 \mathrm{~mm}, L_{C}=400 \mathrm{~mm}$ である。

図16に梁柱接合部材の初期剛性の計算值と実験值の比較を示す。 縦軸と横軸は, 梁せん断力 $Q_{B}$ と層間変形角 $R$ の実験值を, $R-Q_{B}$ 関係の計算值の第 1 折点（梁または柱の曲げひび割れ点）の梁せん 断力 $Q_{B 1}$ と層間変形角 $R_{1}$ でそれぞれ無次元化したものである。扁平 梁の初期剛性の算出では，梁端部補強筋を無視している。

図16に示すように, 初期剛性の計算值は, 第 1 折点（図16の座標 $(1,1)$ の点）では実験結果よりも大きめの值となっているものの, 十分な精度で初期剛性を評価できていると言える。

\section{3 降伏時剛性}

降伏曲げモーメントの算出には, 柱と梁ともに, $\mathrm{RC}$ 規準 ${ }^{10)}$ の梁 の降伏曲げモーメントの略算式を用いた。2 段配筋の場合は，式(1) のように， 1 段目と 2 段目の計算值を足し合わせた。

降伏時剛性の算出には, 次に示すいわゆる菅野式 ${ }^{13)}{ }^{14)}$ を用いる。 $\alpha_{y}=\left(0.043+1.64 n p_{t}+0.043 a / D+0.33 \eta_{o}\right) \cdot(d / D)^{2}$

ただし， $a / D=2 \sim 5, \quad p_{t}=0.4 \sim 2.8 \%, \quad \eta_{o}=0 \sim 0.55$

$\alpha_{y}=\left(-0.0836+0.159 a / D+0.169 \eta_{o}\right) \cdot(d / D)^{2}$

$$
\text { ただし， } a / D=1 \sim 2, p_{t}=0.34 \sim 1.28 \%, \eta_{o}=-0.111 \sim 0.38
$$

$\alpha_{y}$ は降伏時剛性低下率, $n$ は式(3)と同様でヤング係数比, $p_{t}$ は全 断面積に対する引張鉄筋断面積の比, $a$ はせん断スパン, $D$ は部材 成, $d$ は部材の有効成, $\eta_{0}$ は軸力比, である。文献13）にあるよう に, $\alpha_{y}$ は初期剛性に対する降伏時剛性の比で, 初期剛性には式(4) のように鉄筋やせん断変形の影響を考慮すべきだが, 文献13）の資 料では両者の影響が相殺され, 初期剛性にコンクリート部分の初期 曲げ剛性を用いても大差がないとしている。通常, $\alpha_{y}$ はコンクリー 卜部分の初期曲げ剛性の乗数として用いられるので, 降伏時剛性 
$K_{y}$ は次式となる。

$$
K_{y}=\alpha_{y} \cdot\left(3 E_{C} \cdot I_{o} / L_{m}^{3}\right)
$$

初期剛性, 降伏時剛性, 曲げひび割れモーメント, 降伏曲げモー メントより式(2)の $K_{B}$ と $K_{C}$ が得られる。

図17に梁端部補強筋の無い試験体 RC-4 と RC-7の実験結果と計算 結果を示す。実線が実験結果，破線が計算結果である。降伏時剛性 算出では， $a / D$ に応じ，梁には式(6)，柱には式(7)を用いた。これ ら 2 体は梁と柱の接合位置が異なるが, いずれの計算值も実験結果 を精度良く評価できている。梁幅が柱幅の 2 倍程度であれば，標準 タイプと偏心夕イプのいずれも同じ方法で剛性を評価できると言え る。

図18に梁端部補強筋を有する試験体 RC-1と RC-5の実験結果と計 算結果を示す。実線が実験結果，破線が計算結果である。これら 2 体は塑性ヒンジ位置が柱面から離れた試験体だが，簡便な剛性評価 方法を検討するために， $\alpha_{y}$ を算出するときには，梁端部補強筋を 無視し, せん断スパンを加力点から柱面までの距離とした。図18よ り, 計算値は実験結果を十分な精度で評価できている。梁端部補強 筋を考慮した等価断面二次モーメントは, 梁端部補強筋の無い場合 よりも10１5\%増加する程度で，その影響はあまり大きくない。ま た，梁の降伏時には柱面付近にも曲げひび割れが生じていた。塑性 ヒンジ位置が柱面から離れているので, 柱面で降伏する部材とは材 軸方向の曲げ変形の分布は異なるが, 一般に RC 部材の降伏時剛性 にはバラツキがある。これらを考慮すると, 梁端部補強筋を配して 塑性ヒンジ位置を柱面から少し離した場合でも，せん断スパンを柱 面までの距離とすることは簡便且つ十分な精度で評価し得る方法と 言える。

\subsection{2 段配筋の部材の降伏時剛性}

文献13)14）の降伏時剛性低下率の評価式は 1 段配筋の部材を対 象にしたものと思われる。同じ配筋量でも 1 段配筋と 2 段配筋では
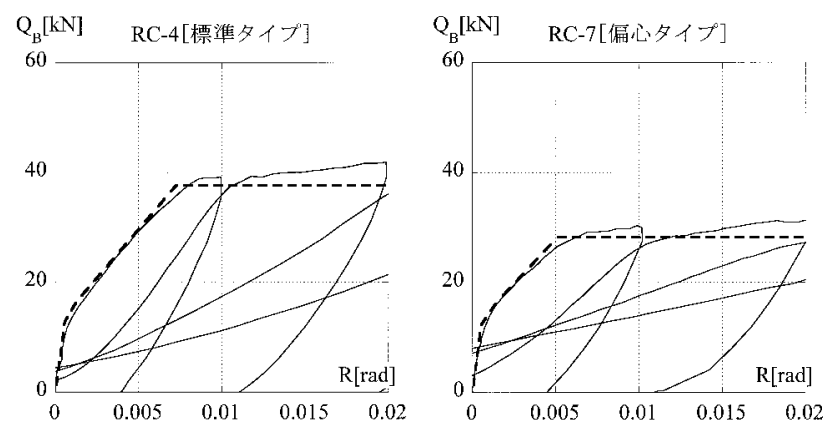

図17 梁せん断力 - 層間変形角関係 (梁端部補強筋の無い試験体)
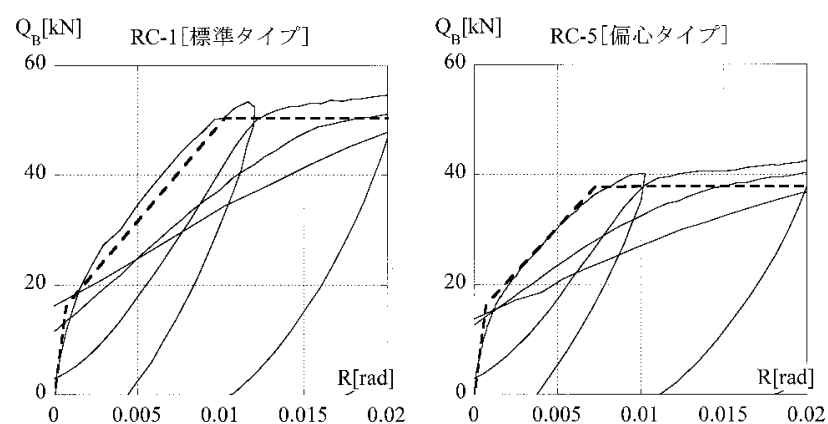

図18 梁せん断力－層間変形角関係（梁端部補強筋を有する試験体）
降伏時剛性が異なると考えられる。ここでは, 式(6)(7)における $d$ と $p_{t}$ に, 等価有効成 $d_{e}$ と等価引張鉄筋比 $p_{t e}$ を算出して代入する方法 について述べる。

式(6)(7)の $d$ を降伏曲げ強度に係るパラメータと考えて, 図19の 2 段配筋の断面の $d_{e}$ を算出する。図19の左図の 2 段配筋の断面の降 伏曲げモーメント $0.9\left(\sum a_{t i} \sigma_{y i} d_{i}\right),(i=1,2)$ が, 右図の等価断面モデル の降伏曲げモーメント $0.9\left(\sum a_{t i} \sigma_{y i}\right) d_{e},(i=1,2)$ に等しいとすると,

$$
d_{e}=\frac{\sum\left(a_{t i} \sigma_{\text {yi }} d_{i}\right)}{\sum\left(a_{t i} \sigma_{y i}\right)} \quad(i=1,2)
$$

となる。本実験の試験体のように，降伏強度の等しい鉄筋を用いた 場合, 式(9)は引張鉄筋の全断面の図心までの距離と一致する。通常, 2 段配筋に強度の大きく異なる鉄筋を用いることはないので, $d_{e}$ は 引張鉄筋の全断面の図心までの距離としても良いと思われる。

式(6)(7)の $p_{t}$ を曲げ剛性に係るパラメータと考え, 図20の上下対 称な 2 段配筋の断面の $p_{t e}$ を算出する。図20の左図の断面と右図の 等価断面モデルの断面二次モーメントを式(3)で計算すると，それぞ れ, $B D^{3} / 12+2 n \sum\left(h_{i}{ }^{2} a_{t i}\right),(i=1,2)$ と, $B D^{3} / 12+2 n(0.4 D)^{2} B D p_{t e}$ になり, これらが等しいと仮定すると次式を得る。

$$
p_{t e}=\frac{\sum h_{i}^{2} a_{t i}}{0.16 B D^{3}} \quad(i=1,2)
$$

図21に試験体 HRC-1，HRC-2の実験結果と計算結果を示す。実線 が実験結果, 破線が $d_{e}$ と $p_{t e}$ を用いた計算結果である。梁の降状時

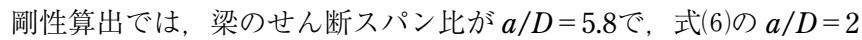
～5の範囲外だが，大きく逸脱しているわけでないので式(6)を用い て算出した。十字形と卜字形の接合部材のいずれにおいても, 計算


図19 等価断面モデルを用いた等価有効成
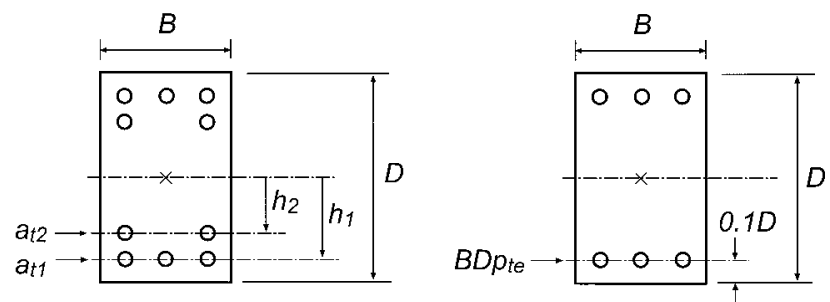

図20 等価断面モデルを用いた等価引張鉄筋比
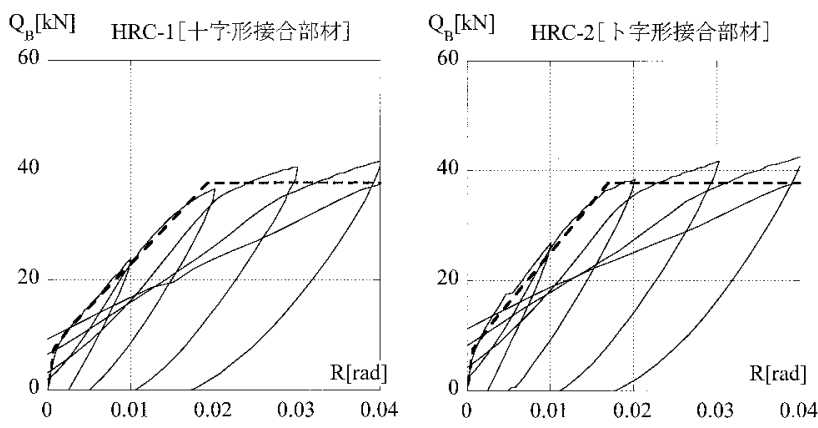

図21 梁せん断力 - 層間変形角関係（2段配筋の試験体） 
結果は実験結果を良く評価できている。 $d_{e}$ と $p_{t e}$ を用いたときの梁 の $\alpha_{y}$ は， $d_{e}$ と $p_{t}$ を用いたときの $\alpha_{y}$ より $15 \%$ 小さく，等価引張鉄筋 比 $p_{t e}$ を用いることは，それなりの効果があると言える。

降状時剛性に与える影響の他の要因としては，鉄筋の高強度化で 降状歪が大きくなることが考えられる。また, 選択できるコンクリー 卜と鉄筋の強度の範囲が広がるので，コンクリート強度と鉄筋の強 度や配筋量のバランスによって, 断面の中立軸位置がかなり変動す ることも考えられる。試験体 HRC-1と HRC-2に用いたコンクリー 卜の圧縮強度は約 $60 \mathrm{~N} / \mathrm{mm}^{2}$, 鉄筋の降状強度は $466 \mathrm{~N} / \mathrm{mm}^{2}$ とそれほ ど高くないので, 式(6)(7)で評価できたと思われる。コンクリートと 鉄筋の高強度化が降状時剛性に与える影響については今後の課題で ある。

\section{5. 結}

高強度材料を用いた RC 扁平梁・柱接合部材の繰り返し加力実験 より, 復元力特性や損傷などについて考察し, 剛性評価を行い, 以 下の結論を得た。ただし，剛性評価については，以前行った普通強 度材料を用いた $\mathrm{RC}$ 扁平梁・柱接合部材の実験の結果 ${ }^{8)}$ も含めて検 討した。

（1）高強度材料を用いた十字形およびト字形接合部材ともに，曲げ 降状型の復元力特性を示し, 梁の曲げ計算強度を発揮した。

(2) 扁平梁・柱接合部材の剛性を線材と接合部パネルに置き換えて 評価する場合，梁幅が柱幅の 2 倍程度であれば，接合部パネル は柱と梁に囲まれた部分のみを考慮し, 扁平梁を全幅が有効と して線材に置き換えることで, 初期剛性や降状時剛性を精度良 く評価できる。

（3）部材の降状時剛性の評価において，2段配筋の影響を考慮する ために，等価有効成と等価引張鉄筋比を用いる方法を示した。

（4）接合部のはね出し部には，ひび割れ軽減のために，据れに抵抗 する補強筋を追加する，卜字形接合部では梁端部補強筋をはね 出し部を囲うように配する，などの改良の余地がある。

（5）接合部付近に設けた貫通孔は，大きな影響を及ぼさなかった。
る研究 一その 4 終局剪断強度算定法とその確証実験一, 日本建築学 会論文報告集，第309号，pp.29-40，1981.11

2）松崎育弘, 福山 洋, 別所佐登志, 畠本 斉: 幅広梁・柱部分架構の復 元力特性に関する実験研究，コンクリート工学年次論文報告集, Vol. 10, No. 3, pp.501-506, 1988

3）木野本圭児, 伊藤光康, 大井貴之, 佐藤則勝: 幅広梁 - 柱部分架構の水 平加力性状に関する実験研究，コンクリート工学年次論文報告集, Vol. 12, No. 2, pp.697-700, 1990

4）高田香織, 津田和明, 江戸宏彰：フラットプレート構造の高層建物への 適用に関する研究 その 1 その 2 , 日本建築学会大会学術講演梗概集 (関東), 構造IV, pp.419-422, 1997.9

5）高田香織，津田和明，佐野剛志，江戸宏彰：フラットプレート構造の高 層建物への適用に関する研究 その 3 その 4 , 日本建築学会大会学術 講演梗概集（九州），構造IV，pp.685-688，1998.9

6）鈴木紀雄, 井上貴之, 永井 覚, 丸田 誠：鉄筋コンクリート造柱一フラッ トスラブ接合部のせん断補強効果に関する実験的研究，コンクリート工 学年次論文報告集，Vol. 21, No. 3, pp.547-552, 1999

7）鈴木紀雄, 井上貴之, 加藤友康 : 鉄筋コンクリート造柱ーフラットスラ ブ接合部のせん断補強法に関する研究（その1）（その 2 ）, 日本建築学 会大会学術講演梗概集（東北），構造 IV, pp.789-792，2000.9

8）西村康志郎, 瀧口克己, 堀田久人, 増井 靖, 常木康弘, 小板橋裕一, 中西則夫 : 鉄筋コンクリート扁平梁構法の開発研究, 日本建築学会構造 系論文集，第616号，pp.179-186，2007.6

9）小嶋一輝，瀧口克己，堀田久人，西村康志郎，小板橋裕一：異形鉄筋に 圧着させた機械式定着金物の性能, 日本建築学会大会学術講演梗概集（九 州), 構造IV, pp.439-440, 2007.8

10）日本建築学会：鉄筋コンクリート構造計算規準・同解説 - 許容応力度 設計法 -, 1999

11）瀧口克己：非線形構造力学 一構造物の多軸挙動と塑性論 - , 数理工学 社, pp.217-234, 2002

12）鈴木敏郎，瀧口克己，岡本哲美，加藤征宏：SRC 部材の復元力特性に対 するフープ筋の効果に関する実験, 日本建築学会構造系論文報告集, 第 348号, pp.61-74, 1985.2

13）菅野俊介：鉄筋コンクリート部材の復元力特性に関する研究 一曲げ降 伏をするはり，柱㧍よび無開口耐震壁の強度と剛性に関する実験的研 究ー、コンクリートジャーナル, Vol. 11，No. 2, pp.1-9, 1973.2

14）菅野俊介, 東端泰夫, 山口育雄：鉄筋コンクリート短柱の崩壊防止に関 する総合的研究 (その 18 : 初ひびわれ時及び降状時の剛性), 日本建築学 会大会学術講演梗概集（北陸），構造系，pp.1323-1324，1974.10

（2007年11月 9 日原稿受理，2008年 1 月 30 日採用決定）

\section{参考文献}

1）狩野芳一, 吉崎征二：フラットプレート構造の柱ースラブ接合部に関す 